p. 20, enhances the interest with which anthropologists will await further particulars of the human skull which, it is announced, Prof. T. F. Dreyer, of Grey University College, Bloemfontein, has discovered at Florsbad hot springs. According to a message in the Times for July 27, Prof. Dreyer has found parts of a human skull and a tooth, associated with stone implements of a primitive type and the remains of extinct fauna on this site, which lies twenty-five miles north of Bloemfontein. The lower jaw is missing, but, it is said, most of the facial bones are present. The character of the skull cannot be determined with certainty until the base has been found; but Prof. Dreyer is reported to be of the opinion that it is that of either Neanderthal man or Rhodesian man. According to the measurement of the skull " over the eyes ", it would hold a place intermediate between the two, the figure given being $130 \mathrm{~mm}$., as against the maximum in Neanderthal man of $125 \mathrm{~mm}$. and $139 \mathrm{~mm}$. in Rhodesian man. These figures, slender evidence as they are, are certainly suggestive of the possible significance of the new find in relation to the affinities of early types of man in South Africa. Should it appear eventually that the skull is a second specimen of Rhodesian man, its association with stone imple. ments and extinct fauna should provide the much desired evidence indicating the geological age and the culture of that remarkable type of primitive man.

\section{Exhibition of British Archæology}

AN exhibition illustrative of recent field-work in British archæology was arranged at the London Museum in connexion with the International Congress of Prehistoric and Protohistoric Seienees which met in London on Aug. 1-6. Its primary object was to afford visitors from abroad some idea of the range and value of the material which archæological investigation in Great Britain is adding to the study of prehistoric and early historic times; but it was also intended to interest and inform other visitors to the Museum whose acquaintance with archæological studies might not be sufficiently intimate to keep them abreast with the activities of our research workers in the various provinces of the subject. The exhibits ranged from the pre-palæolithic discoveries of Mr. Reid Moir in East Anglia to the objects of late Saxon and Viking times from districts so far removed from one another as Durham and Dorset. The choice of sites illustrated was discriminating and the number of objects shown kept as low as possible, consistently with the aim of making the exhibition representative. It is, therefore, difficult to single out any one or two exhibits as especially worthy of note. Colchester and Verulamium naturally figured prominently, as also did Mr. A. Koiller's exhibit from the Windmill Hill site. No doubt many visitors were glad to avail themselves of Mr. Keiller's offer of admission to view the complete collection of finds shown at Charles Street, Berkeley Square. The interest of the exhibition was much enhanced by the magnificent series of photographs from the air of various classes of site which was lent by the Ordnance Survey and described in an admirable catalogue. An excellent descriptive catalogue was also prepared for the archæological exhibits. Probably it will be a long time before so completely representative a collection, drawn from widely distributed places of permanent exhibition, will be gathered together again.

\section{Methods in Anthropometry}

For a considerable period it has been apparent that the time was ripe for a measure of revision of the methods of anthropometry, although caution was enjoined by a not unnatural reluctance to take any steps which might lessen the value, for comparative purposes, of thousands of measurements taken by generations of anthropologists in the field and laboratory. The feeling of dissatisfaction with existing methods, however, both among British and Continental anthropologists, was sufficiently strong to warrant discussion; but it cannot be said that anything practical had emerged until recently, when certain suggestions were put forward jointly by Miss M. L. Tildesley, Dr. E. G. Morant, and Dr. L. H. Dudley Buxton as a report to the council of the Royal Anthropological Institute. Briefly, these suggestions are that for the moment there should be an agreed abbreviated technique of observations in anthropometry, confined to the racial characters of adults of both sexes ; and that this should be determined and elaborated as required by an international committee. But it is put forward as a first step that a technique should be formulated for Great Britain and Ireland; and at the same time representative bodies in other countries should be invited to do the same for their areas, with the view of international discussion later. The proposal, with further suggestions as to detail, will be found in Man for July. While this courageous attempt to deal with a difficult situation scarcely calls for comment at the present stage, it may be pointed out that without an assurance of external support the proposal risks a great deal of wasted affort. British anthropologists cannot work in isolation, however considerable the proportion of their output in the world of anthropometric science may be.

\section{Changes in Scientific Outlook}

Sir OLIver LoDGE on March 17 gave the oration at the thirty-sixth Foundation Week at University College, London. It was well received at its delivery, and is well worth reading in its published form (University of London Press, 1s. net). Sir Oliver is now so generally accepted as the best exponent of a tolerant, humane, and comprehensive way of regarding science that when he speaks, as he did, on "Changes in Scientific Outlook", he might expect an attentive audience. The address was eloquent, impressive, and highly stimulating to thought, but it scarcely covered the matter which the title would lead one to expect. There is little or nothing in it of the latest developments in science, the extension of specialisation, the connexions of astrophysics with laboratory work, the exploration of the border-line problems between animate and inanimate. Sir Oliver practically confined himself to the one issue which in his view outweighs in ultimate importance all the others, and the address might well be called "A Plea

$$
\text { No. 3275, VoL. 130] }
$$

